B EYOND THE NATION-STATE 
This page intentionally left blank 


\title{
BEYOND THE
}

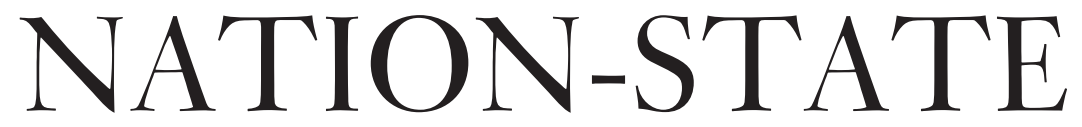

The Zionist Political Imagination from Pinsker to Ben-Gurion

\section{DMITRY SHUMSKY}

\author{
Yale
}

UNIVERSITY PRESS

New Haven and London 
Published with assistance from the foundation established in memory of Amasa Stone Mather of the Class of I907, Yale College.

Copyright (C) 2018 by Yale University.

All rights reserved.

This book may not be reproduced, in whole or in part, including illustrations, in any form (beyond that copying permitted by Sections I07 and Io8 of the U.S. Copyright Law and except by reviewers for the public press), without written permission from the publishers.

Yale University Press books may be purchased in quantity for educational, business, or promotional use. For information, please e-mail sales.press@yale.edu (U.S. office) or sales@yaleup.co.uk (U.K. office).

Set in Janson type by Integrated Publishing Solutions. Printed in the United States of America.

Library of Congress Control Number: 2018933964

ISBN 978-0-300-230I3-o (hardcover : alk. paper)

A catalogue record for this book is available from the British Library.

This paper meets the requirements of ANSI/NISO Z $39 \cdot 48$ - 1992

(Permanence of Paper).

I0 987765432 I 
For Innochka, Anat, and Ben 
This page intentionally left blank 